\title{
PERFORMACE OF DILUTE NITRIDE TRIPLE JUNCTION SPACE SOLAR CELL GROWN BY MBE
}

\author{
Arto Aho, Riku Isoaho, Antti Tukiainen, Ville Polojärvi, Marianna Raappana, Timo Aho, Mircea Guina
}

Tampere University of Technology, Optoelectronics Research Centre, Korkeakoulunkatu 3, 33720 Tampere, Finland, Email:arto.j.aho@tut.fi

\begin{abstract}
Dilute nitride arsenide antimonide compounds offer widely tailorable band-gaps, ranging from $0.8 \mathrm{eV}$ to 1.4 $\mathrm{eV}$, for the development of lattice-matched multijunction solar cells with three or more junctions. Here we report on the performance of $\mathrm{GaInP} / \mathrm{GaAs} / \mathrm{GaInNAsSb}$ solar cell grown by molecular beam epitaxy. An efficiency of $27 \%$ under AM0 conditions is demonstrated. In addition, the cell was measured at different temperatures. The short circuit current density exhibited a temperature coefficient of $0.006 \mathrm{~mA} / \mathrm{cm}^{2} /{ }^{\circ} \mathrm{C}$ while the corresponding slope for the open circuit voltage was $-6.8 \mathrm{mV} /{ }^{\circ} \mathrm{C}$. Further efficiency improvement, up to $32 \%$, is projected by better current balancing and structural optimization.
\end{abstract}

\section{INTRODUCTION}

Commercial space solar cells have reached $30 \%$ beginning of life (BOL) efficiencies [1]. For even higher efficiencies and more efficient spectral utilization, the development of new materials is needed. In lattice matched GaInP/GaInAs/Ge cell the spectral range from $0.7 \mathrm{eV}$ to $1.4 \mathrm{eV}$ is covered by the Ge sub-junction. In this case, there is a high overall quantum defect between photon energies and the band-gap energy of Ge leading to inefficient energy conversion. Consequently, Ge junction is generating approximately only $0.2 \mathrm{~V}$. Lattice matched $1 \mathrm{eV}$ band-gap dilute nitrides, such as GaInNAsSb alloys, offer lower quantum defect and higher voltage generation. The best band-gap voltage offset value demonstrated for dilute nitride junction is $0.49 \mathrm{~V}$ [2]. Therefore, with current balanced $\sim 1 \mathrm{eV}$ dilute nitride junction, up to $0.3 \mathrm{~V}$ higher operation voltage could be produced than with Ge junction. Projective calculations based on diode modelling and the measured performance of dilute nitride cells have shown that for realistic $\mathrm{GaInP} / \mathrm{GaAs} / \mathrm{GaInNAsSb}$ design, the BOL efficiency could increase approximately 3 percentage points when compared to a Ge-based cell [3]. Moreover, the incorporation of dilute nitrides in a four junction cell with Ge bottom junction could give additional 2 percentage points higher efficiency, yielding ultimately $35 \%$ BOL efficiency [3]. Here we demonstrate a triple junction $\mathrm{GaInP} / \mathrm{GaAs} / \mathrm{GaInNAsSb}$ solar cell grown by molecular beam epitaxy (MBE), which sets a roadmap towards demonstrating higher efficiencies and solar cells incorporating higher number of junctions.

\section{EXPERIMENTS}

The GaInP/GaAs/GaInNAsSb solar cell structure was grown monolithically on $\mathrm{p}-\mathrm{GaAs}$ substrate using a Veeco GEN20 MBE-system. Detailed description for the fabrication process can be found elsewhere [4, 5]. Subsequent to the growth, the wafer was processed into $4 \times 4 \mathrm{~mm}^{2}$ solar cells. TiAu and NiAu alloys were used for p- and n-side contacts, respectively. For anti-reflection coating, we used a double-layer $\mathrm{TiO}_{\mathrm{x}} / \mathrm{SiO}_{\mathrm{x}}$ thin film [6]. For the measurements, we used a spectrally adjustable inhouse built three-band solar simulator, which was set to AM0 spectral conditions with separately calibrated single junction GaInP, GaAs and GaInNAsSb cells. ASTM E490 AM0 spectrum $\left(1366 \mathrm{~W} / \mathrm{m}^{2}\right)$ [7] was used for reference. External quantum efficiency (EQE) measurements were performed using an in-house built, monochromator based, measurement system. In addition, for different spectral regions, proper set of band pass filters were used, which ensures monochromatic probe beam. The EQE system response was calibrated with $\mathrm{Si}$ and Ge detectors. For the performance analysis and performance projections we used diode modelling employing the parametrization described earlier $[3,8]$.

\section{RESULTS AND DISCUSSION}

The current-voltage (I-V) performance of the GaInP/GaAs/GaInNAsSb cell illuminated with AM0 three band solar simulator is shown in Fig. 1a. The short circuit current density $\left(J_{\mathrm{sc}}\right)$ was $17.2 \mathrm{~mA} / \mathrm{cm}^{2}$. Our analysis concluded that the cell was current limited by the GaInP top cell. The open circuit voltage $\left(V_{\text {oc }}\right)$ and fill factor $(F F)$ were $2.67 \mathrm{~V}$ and $80 \%$, respectively. The band-gaps for GaInP/GaAs/GaInNAsSb cell are $1.9 \mathrm{eV}$, $1.4 \mathrm{eV}$ and $0.98 \mathrm{eV}$, respectively. These values are revealed by the EQE measurement performed at $22^{\circ} \mathrm{C}$, which is shown in Fig. 1b. In addition, Fig. $1 \mathrm{~b}$ reveals the EQE measurement at $80^{\circ} \mathrm{C}$. The $J_{\text {sc }}$ for the sub-junctions calculated using the EQE measurements are presented in the Tab. 1. For the GaAs sub-junction, the limiting current was estimated from both EQE and using a three band solar simulator measurements to give realistic values. For GaInP top cell and for GaInNAsSb bottom cell the values were directly calculated from the EQE measurements and AM0 spectrum. 
Table 1. Analysis of the EQE measurements.

\begin{tabular}{lllll}
\hline Sub-cell & $\begin{array}{l}\text { Band- } \\
{\text { gap } 22^{\circ} \mathrm{C}}_{(\mathrm{eV})}\end{array}$ & $\begin{array}{l}J_{\mathrm{sc} 22^{\circ} \mathrm{C}} \\
(\mathrm{mA} / \\
\left.\mathrm{cm}^{2}\right)\end{array}$ & $\begin{array}{l}\text { Band- } \\
\mathrm{gap}_{80^{\circ} \mathrm{C}} \\
(\mathrm{eV})\end{array}$ & $\begin{array}{l}\Delta J_{\mathrm{sc}\left(25 \rightarrow 80^{\circ} \mathrm{C}\right)} \\
(\mathrm{mA} / \\
\left.\mathrm{cm}^{2}\right)\end{array}$ \\
\hline GaInP & 1.88 & 17.1 & 1.85 & +0.4 \\
GaAs & 1.41 & $17.7 *$ & 1.37 & +0.4 \\
GaInNAsSb & 0.98 & 18.5 & 0.96 & -0.2 \\
\hline
\end{tabular}

*Limited EQE measurement performance for the GaAs sub-junction, $J_{\mathrm{sc}}$-values are estimated for GaAs cell based on the EQE and solar simulator measurements.

For the absolute comparison and projective analysis of $\mathrm{GaInP} / \mathrm{GaAs} / \mathrm{GaInNAsSb}$ cell performance, diode modelled $I-V$-characteristics of a current matched cell are also presented in Fig. 1a. The comparison reveals that with further current matching and band-gap tuning, 4 percentage points higher efficiencies are projected for the optimized $\mathrm{GaInP} / \mathrm{GaAs} / \mathrm{GaInNAsSb}$ cell. For better current matching, structural optimization is needed for GaInP and GaAs sub-cells, which we have started with very promising results. Therefore, we believe that the $J_{\mathrm{sc}}$ can be increased at least to $17.7 \mathrm{~mA} / \mathrm{cm}^{2}$. The triple junction cell has $0.18 \mathrm{~V}$ lower $V_{\text {oc }}$ than the simulated cell. This voltage drop can be reduced with band-gap engineering and material improvements.
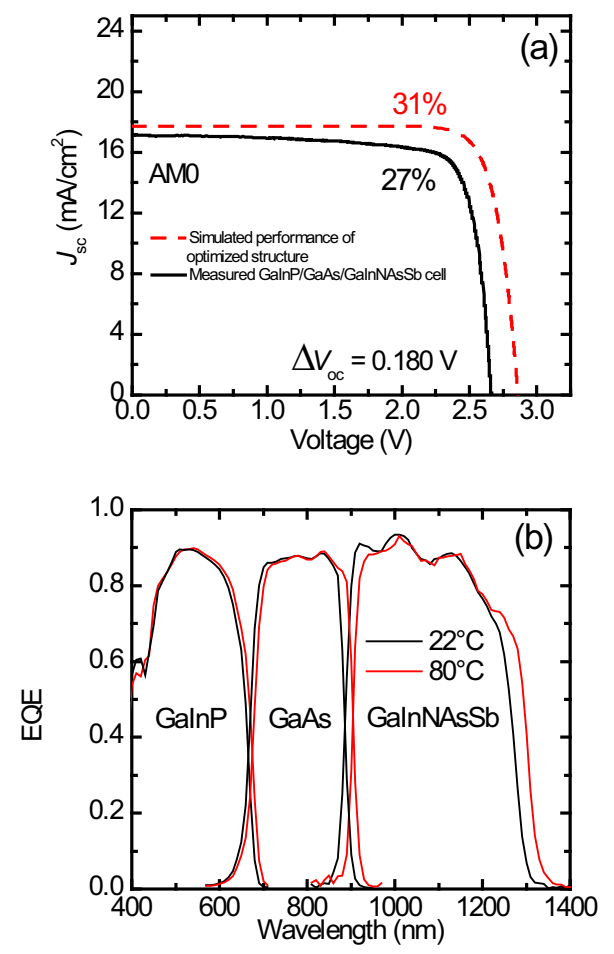

Figure 1. (a) AMO biased IV-characteristics of GaInP/GaAs/GaInNAsSb solar cell and the simulated performance of GaInP/GaAs/GaInNAsSb cell. (b) EQE characteristics of GaInP/GaAs/GaInNAsSb solar cell measured at $22^{\circ} \mathrm{C}$ and $80^{\circ} \mathrm{C}$.
Approximately $0.1 \mathrm{~V}$ higher $V_{\text {oc }}$ can be obtained by using higher band-gap for the GaInNAsSb junction. For the remaining voltage gap of $0.08 \mathrm{~V}$, structural and material quality optimizations are the key factors. Ultimately, additional 0.05-0.09 $\mathrm{mV}$ improvement for the GaInNAsSb sub-junction might be expected with optimization and improved design, yielding efficiency as high as $32 \%$ for the triple junction cell.

Moreover, the temperature coefficients for the cell were defined by the $I-V$ measurements performed in the temperature range of $25-90^{\circ} \mathrm{C}$. The relative change of the $J_{\text {sc }}$ value for the $\mathrm{GaInP} / \mathrm{GaAs} / \mathrm{GaInNAsSb}$ cell is presented in Fig. 2a, while Fig. 2b shows the dependence on the cell $V_{\mathrm{oc}}$ as the function of the cell temperature. The $J_{\text {sc }}$ temperature coefficient was $0.006 \mathrm{~mA} / \mathrm{cm}^{2} /{ }^{\circ} \mathrm{C}$ while the corresponding value for $V_{\text {oc }}$ was $-6.8 \mathrm{mV} /{ }^{\circ} \mathrm{C}$. The $J_{\mathrm{sc}}$ temperature coefficient calculated from EQE was also $0.006 \mathrm{~mA} / \mathrm{cm}^{2}$.
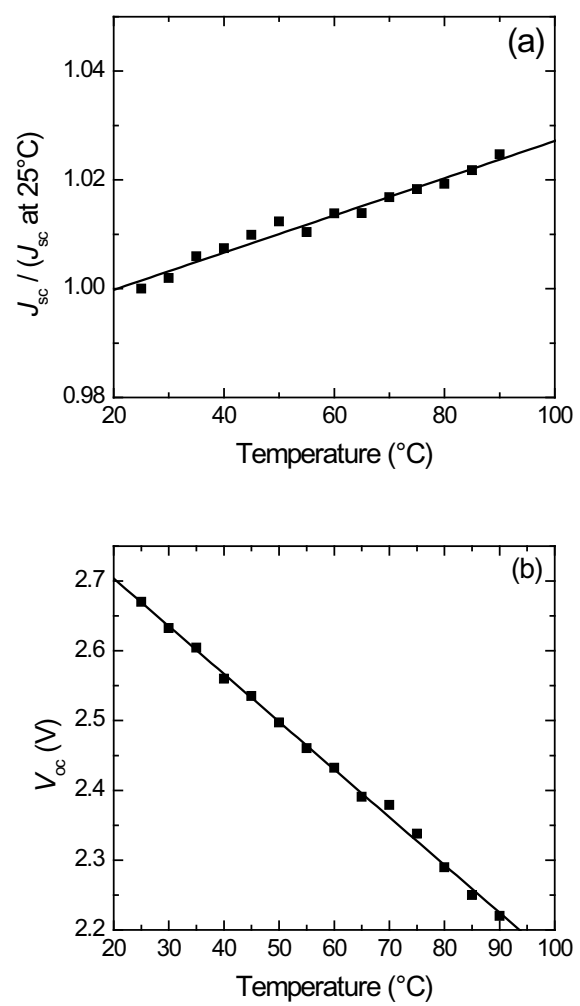

Figure 2. (a) Temperature dependent $J_{s c}$ normalized to $J_{s c}$ at $25^{\circ} \mathrm{C}$. (b) Temperature dependence of $V_{o c}$ for GaInP/GaAs/GaInNAsSb cell.

\section{CONCLUCION AND FUTURE WORK}

We have demonstrated a high performance $\mathrm{GaInP} / \mathrm{GaAs} / \mathrm{GaInNAsSb}$ space solar cell with an efficiency of $27 \%$ at AM0 conditions. Using realistic diode model simulation, we show that the efficiency of $\mathrm{GaInP} / \mathrm{GaAs} / \mathrm{GaInNAsSb}$ cell could reach 31\%, following current matching and band-gap optimization of 
the dilute nitride bottom cell. Ultimately, with further optimization of the triple junction cell interfaces and material quality, an BOL efficiency as high as $32 \%$ is feasible. We also determined the temperature coefficients for $J_{\mathrm{sc}}$ and $V_{\mathrm{oc}}$, which were $0.006 \mathrm{~mA} / \mathrm{cm}^{2} /{ }^{\circ} \mathrm{C}$ and $6.8 \mathrm{mV} /{ }^{\circ} \mathrm{C}$, respectively.

\section{ACKNOWLEDGEMENTS}

The authors acknowledge the financial support provided by the Finnish Funding Agency for Technology and Innovation, Tekes (projects 'Solar III-V' \#40120/09 and 'Nextsolar' \#40239/12). This work was also partly performed under a programme of and funded by the European Space Agency (contract N.: 4000108058/13/NL/FE). The view expressed herein can in no way be taken to reflect the official opinion of the European Space Agency.

\section{REFERENCES}

1. A. W. Bett, F. Dimroth, W. Guter, R. Hoheisel, E. Oliva, S. P. Philipps, J. Schöne, G. Siefer, M. Steiner and A. Wekkeli (2009). Highest efficiency multi-junction solar cell for terrestrial and space applications. 24th European Photovoltaic Solar Energy Conference. 21-25 September 2009, Hamburg, Germany, pp1-6.

2. J. Tommila, A. Aho, A. Tukiainen, V. Polojärvi, J. Salmi, T. Niemi and M. Guina. Moth-eye antireflection coating fabricated by nanoimprint lithography on $1 \mathrm{eV}$ dilute nitride solar cell. Prog. Photovoltaics Res. Appl. vol. 21. pp1158-1162.

3. A. Aho, A. Tukiainen, V. Polojärvi and M. Guina, "Dilute Nitride Space Solar Cells: Towards 4 Junctions," 10th European Space Power Conference ESPC 2014, 13-17 April, 2014, Noordwijkerhout, the Netherlands, vol. 719, pp1-3, 2014.

4. A. Aho, R. Isoaho, A. Tukiainen, V. Polojärvi, T. Aho, M. Raappana and M. Guina. (2015). Temperature coefficients for GaInP/GaAs/GaInNAsSb solar cells. AIP Conference Proceedings. vol. 1679.

5. A. Aho, V. Polojärvi, V. -M. Korpijärvi, J. Salmi, A. Tukiainen, P. Laukkanen and M. Guina. (2014). Composition dependent growth dynamics in molecular beam epitaxy of GaInNAs solar cells. Solar Energy Mater. Solar Cells. vol. 124, pp150158.

6. A. Aho, J. Tommila, A. Tukiainen, V. Polojärvi, T. Niemi and M. Guina. (2014). Moth eye antireflection coated GaInP/GaAs/GaInNAs solar cell. AIP Conference Proceedings 1616. pp33-36.

\section{DOI: http://dx.doi.org/10.1063/1.4897022.}

7. ASTM E490: Standard tables for AM0 reference solar spectral irradiances.

8. A. Aho, A. Tukiainen, V. Polojärvi and M. Guina, Performance assessment of multijunction solar cells incorporating GaInNAsSb. Nanoscale Res. Lett. vol. 9, pp1-7. 